SYSTEMATICS AND PHYLOGENY

\title{
The Strepsiptera-Odyssey: the history of the systematic placement of an enigmatic parasitic insect order
}

\author{
H. Pohl, R.G. Beutel \\ Friedrich-Schiller-University Jena, Germany
}

\begin{abstract}
The history of the phylogenetic placement of the parasitic insect order Strepsiptera is outlined. The first species was described in 1793 by P. Rossi and assigned to the hymenopteran family Ichneumonidae. A position close to the cucujiform beetle family Rhipiphoridae was suggested by several earlier authors. Others proposed a close relationship with Diptera or even a group Pupariata including Diptera, Strepsiptera and Coccoidea. A subordinate placement within the polyphagan series Cucujiformia close to the woodassociated Lymexylidae was favored by the coleopterist R.A. Crowson. W. Hennig considered a sistergroup relationship with Coleoptera as the most likely hypothesis but emphasized the uncertainty. Cladistic analyses of morphological data sets yielded very different placements, alternatively as sistergroup of Coleoptera, Antliophora, or all other holometabolan orders. Results based on ribosomal genes suggested a sistergroup relationship with Diptera (Halteria concept). A clade Coleopterida (Strepsiptera and Coleoptera) was supported in two studies based on different combinations of protein coding nuclear genes. Analyses of data sets comprising seven or nine genes (7 single copy nuclear genes), respectively, yielded either a subordinate placement within Coleoptera or a sistergroup relationship with
\end{abstract}

Correspondence: Rolf Georg Beutel, Entomology Group, Institut für Spezielle Zoologie und Evolutionsbiologie mit Phyletischem Museum, Erbertstrasse 1, Friedrich-Schiller-University Jena, 07743 Germany.

Tel. +49.3641.949140 - Fax: +49.3641.949142.

E-mail: rolf.beutel@uni-jena.de

Key words: Strepsiptera, phylogeny, placement, history.

Contributions: the authors contributed equally.

Acknowledgements: support for investigations related to this study came from the German Science Foundation (DFG, BE 1789/8-1). This is gratefully acknowledged.

Received for publication: 29 April 2013.

Accepted for publication: 4 July 2013.

This work is licensed under a Creative Commons Attribution NonCommercial 3.0 License (CC BY-NC 3.0).

CC Copyright H. Pohl and R.G. Beutel., 2013

Licensee PAGEPress, Italy

Entomologia 2013; 1:e4

doi:10.4081/entomologia.2013.e4
Neuropterida. Several early hypotheses based on a typological approach - affinities with Diptera, Coleoptera, a coleopteran subgroup, or Neuropterida - were revived using either a Hennigian approach or formal analyses of morphological characters or different molecular data sets. A phylogenomic approach finally supported a sistergroup relationship with monophyletic Coleoptera.

«Systemata entomologica perturbare videtur cum ex ordinibus omnibus repellatur - animalculum - animum excrucians. Tempus ducamus, et dies alteri lucem afferent.»

[We see the entomological system confused, and that it (the strepsipteran) bounces out from all orders. The little critter gets on our nerves. Time will show, and other days will bring light in this matter.]

Latreille, 1809

\section{Introduction}

Strepsiptera are arguably one of the most enigmatic and fascinating groups of Hexapoda (e.g., Pierce, 1909; Ulrich, 1943; Kinzelbach, 1971a; Kathirithamby, 1991, 2009; Pohl \& Beutel, 2008). The highly specialized insects were addressed as twisted parasites from outer space (Proffitt, 2005) and the term The Strepsiptera problem was coined by Kristensen (1981) referring to the tremendously difficult phylogenetic placement (e.g., Kinzelbach, 1990; Kristensen, 1999; Beutel \& Pohl, 2006a; Trautwein et al., 2012). Systematic affinities with many different groups of insects were suggested since the first species was discovered by Rossius (1793), and strong controversies continued until very recently (e.g., McKenna \& Farell, 2010; Ishiwata et al., 2011; Niehuis et al., 2012).

Strepsiptera are one of the smallest groups of holometabolan insects. Approximately 600 extant species are described and a limited number of fossils (e.g., Kinzelbach \& Pohl, 1994; Grimaldi et al., 2005; Pohl et al., 2005). One characteristic feature is the obligatory endoparasitism of larvae (all extant groups) and of the females of all but two families (Stylopidia, ca. 97\% of the known species) (see Kathirithamby, 2009 for a review). This is linked with hypermetamorphosis, with extremely small first instar larvae (Pohl, 2000), and with a strong structural simplification of the secondary larval stages (e.g., Pohl \& Beutel, 2008). The specific type of parasitism has apparently also resulted in far-reaching morphological modifications in the short-lived adults males, and to an even higher degree in the females, especially the endoparasitic ones (Stylopidia).

Strepsiptera have always attracted the attention of entomologists (see e.g., Kinzelbach, 1978; Kathirithamby, 1991). Milestones were studies by Ulrich (e.g., 1927a,b 1943, 1956, 1966) and Kinzelbach (e.g., 
$1967,1971 \mathrm{a}, \mathrm{b}, 1978,1990)$. In the last decades the investigation of the group accelerated, with an impressive number of studies on the larval morphology (e.g., Pohl, 2000; Beutel et al., 2005; Osswald et al., 2009), the morphology of adults (e.g., Beutel \& Pohl, 2006; Beutel et al., 2005; Pohl \& Beutel, 2004, 2005; Hünefeld \& Beutel, 2005; Koeth et al., 2012), taxonomy (e.g., Kathirithamby, 1989; Pohl et al., 2012), fossils (e.g., Kathirithamby \& Grimaldi, 1993; Kinzelbach \& Pohl, 1994; Grimaldi et al., 2005; Pohl, 2009; Pohl et al., 2005, 2010; Hünefeld et al., 2011), host parasite associations (e.g., Kathirithamby, 2009), biochemistry (Cvačka et al., 2012; Tolasch et al., 2012), genetics (Johnston et al., 2004; Niehuis et al., 2012) and the phylogeny and evolution based on morphological characters (e.g., Pohl, 2002; Pohl \& Beutel, 2005; Bravo et al., 2009) and molecular data (McMahon et al., 2011; Niehuis et al., 2012).

The purpose of the present study is to give an overview of the history of the systematic placement of Strepsiptera and to elucidate effects of different systematic approaches.

\section{Materials and Methods}

The information provided here was entirely extracted from the literature (e.g., Ulrich, 1943; Hennig, 1969; Kinzelbach, 1971a,b; Kathirithamby, 1989, 1991). However, the interpretations are backed up by intensive research on the phylogeny and other aspects of the group over more than a decade (e.g., Pohl, 2000; Beutel \& Pohl, 2006b; Pohl \& Beutel, 2005, 2008; Pohl et al., 2005, 2012; Bravo et al., 2009; Koeth et al., 2012; Niehuis et al., 2012).

\section{Results}

\section{Discovery and early systematic assignments}

The first strepsipteran species was discovered in the late eighteenth century by P. Rossi (Rossius, 1793). Based on the endoparasitic habits, the author assigned the species Xenos vesparum, a parasite of the vespid Polistes Linnaeus, to the hymenopteran family Ichneumonidae. Kirby (1802) described the species Stylops melittae parasitizing andrenid bees and later introduced the separate order Strepsiptera (Kirby, 1815) (Table 1). In contrast to Rossi (Rossius 1793) the prominent French zoologist P.A. Latreille placed Xenos vesparum in a dipteran group Phthiromyae (Latreille, 1809) but later removed it as a separate order Rhipiptera (Latreille 1817; see also Jeannel, 1951). A close association with a dipteran group, in this case Rhipidoptera, was hypothesized by the famous evolutionary biologist J.B. de Lamarck (Lamarck, 1816). Like strepsipterans, the megadiverse holometabolan order Diptera is characterized by halteres, wings modified as club-shaped gyroscopic sense organs (Ulrich, 1930; Pix et al., 1993). However, these structures are inserted on different thoracic segments in the two groups. The more or less intuitive placement of Lamarck (1816) was later followed by Newman (1834) who studied the morphology of a species of Stylops, and also by Pierce (1918). Newman's study (Newman, 1834) was already heavily criticized by Westwood (1939). Nevertheless, Pierce $(1936,1952)$ united the strepsipterans with Diptera and Coccidina (Sternorrhyncha, Acercaria) in a group Pupariata, based on the puparium occurring in the postembryonic development of these lineages, the occurrence of wingless females, ovovivipary, and the presence of balancers. Even by that time this implied ignoring (or violating) well established (and later confirmed) systematic units such as the widely accepted Hemiptera (or Hemipteroidea) and Holometabola (e.g., Weber, 1933; Snodgrass, 1935). As it was often the case in earlier attempts to classify insects or other groups of organisms (Typologie, see e.g., Beutel et al., 2009), one character complex was arbitrarily selected as a criterion for unifying groups, in this case the formation of a puparium.

Burmeister (1837) in his Handbuch der Naturgeschichte suggested a placement close to the parasitic beetle family Ripiphoridae for the first time. Both groups share endoparasitic habits, a hypometamorphic postembryonic development, and very small and quite similar primary larvae (triungulins) (Figure 1). Moreover adults of some ripiphorid species are strikingly similar to strepsipteran males, with flabellate antennae, strongly reduced mouthparts, and distinctly reduced elytra almost resembling halteres (Figure 2). The hypothesis suggested by Burmeister (1837) was followed by several other $19^{\text {th }}$ century researchers such as for instance the French coleopterists T. Lacordaire and J. L. LeConte (e.g., Schaum, 1865; Saunders, 1872; Lawrence \& Newton, 1995).

A relationship with Coleoptera was also suggested by the palaeoentomologist Handlirsch (1903), however in an ambivalent way. Whereas his tree (first table presented in Handlirsch, 1903) suggests a sistergroup relationship between both orders his statement von Coleopteren abstammen (descendants of coleopterans) suggests a subordinate placement. Based on posteromotorism (metathorax as main or exclusive flight organ) and related features a close relationship between Strepsiptera and Coleoptera was also supported by Börner (1904) in a study on the phylogeny of Hexapoda. The same concept was implicitly used by Shipley (1904) who listed both groups as neighboring independent orders.

In a detailed discussion of thoracic characters Crampton (1931) pointed out correctly that possible affinities of Strepsiptera and Ripiphoridae are based on rather superficial similarities of the larvae,
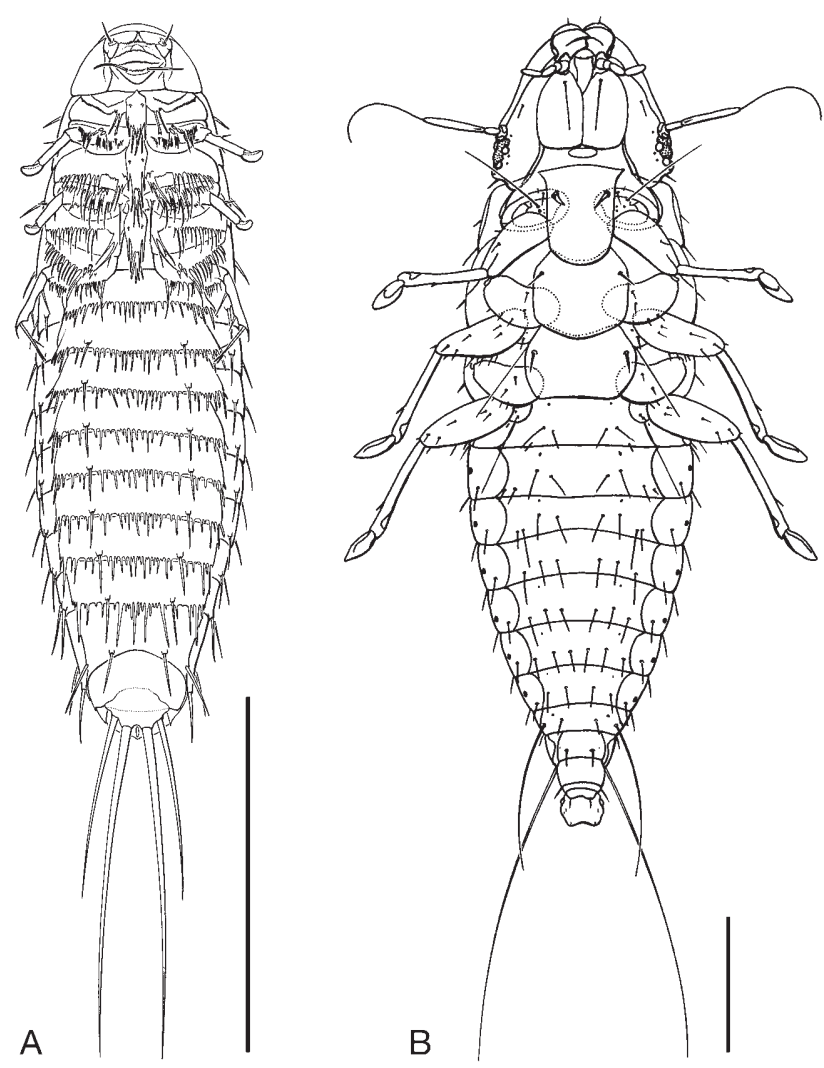

Figure 1. A. First instar larva of Eoxenos laboulbenei (Strepsiptera, Mengenillidae), ventral view. B. First instar larva of Macrosiagon ferrugineum (Coleoptera, Ripiphoridae), ventral view. Scale bars $=100 \mu \mathrm{m}$. (A. Modified from Pohl 2000; B. Modified from Grandi 1936). 
Table 1. Sytematic placements of Strepsiptera with different approaches and data.

\begin{tabular}{|c|c|c|}
\hline Systematic approach/study & Characters & Systematic placement \\
\hline \multicolumn{3}{|c|}{ Pre-Hennigian concepts } \\
\hline Rossius (1793) & Parasitism & Hymenoptera (Ichneumonidae) \\
\hline Latreille (1809) & Morphology and development & Diptera (Phthiromyae) \\
\hline Latreille (1817) & & Strepsiptera as separate order Ripiptera \\
\hline Lamarck (1816) & Morphology and development & Diptera \\
\hline Newman (1834) & Morphology and development & Diptera \\
\hline Burmeister (1836) & Morphological similarity & Close to Ripiphoridae (Coleoptera, Cucujiformia) \\
\hline Schiødte (1862/63) & Morphological similarity of larvae & Close to Ripiphoridae (Coleoptera, Cucujiformia) \\
\hline $\begin{array}{l}\text { Gerstaecker in Peters et al. } \\
(1863-1875)\end{array}$ & Larval morphology (based on Newport) & $\begin{array}{l}\text { Neuroptera (Neuropterida, Trichoptera, Mecoptera), } \\
\text { closest to Phryganaeidae (Trichoptera) }\end{array}$ \\
\hline Pierce $(1936,1952)$ & Puparium & ariata, Strepsiptera united with Diptera and Coccoidea (Hemiptera) \\
\hline Crampton (1931) & Metathoracic features & Common ancestor with Coleoptera \\
\hline Bohart (1941) & Morphology & Closely allied to Coloptera \\
\hline Jeannel $(1945,1951)$ & Morphology, parasitism & Within Hymenoptera (apparenté aux Hymenoptères Symphytes) \\
\hline Crowson (1955) & Informal character discussion & Subgroup of Cucujiformia (Polyphaga, Coleoptera) \\
\hline Crowson (1981) & Informal character discussion & rroup of Cucujiformia (Polyphaga, Coleoptera), close to Lymexylidae \\
\hline \multicolumn{3}{|c|}{ Hennigian concepts } \\
\hline Kinzelbach (1967) & Cephalic morphology & $\begin{array}{l}\text { Close relationship with Mecopterida } \\
\text { (Mecopteroid complex, Trichoptera, Zeugloptera, Lepidoptera) }\end{array}$ \\
\hline Hennig (1969) & Discussion of morphological characters & Tentatively as sistergroup of Coleoptera (fig. 95) \\
\hline Kinzelbach (1971a) & Discussion of morphological characters & Sistergroup of Coleoptera \\
\hline Boudreaux (1979) & Mainly characters discussed by Kinzelbach (1971) & Sistergroup of Coleoptera \\
\hline Kathirithamby (1991) & Posteromotorism & Sistergroup of Coleoptera \\
\hline Kristensen (1999) & Discussion of morphological and developmental characters & $\begin{array}{c}\text { Unresolved between Coleoptera + Neuropterida and } \\
\text { Hymenoptera + Mecopterida, possibly sistergroup } \\
\text { of remaining Holometabola }\end{array}$ \\
\hline Willmann (2005) & Discussion of morphological characters & Sistergroup of Coleoptera \\
\hline Kukalová-Peck \& Lawrence (1993) & Wing base and venation & Sistergroup of Coleoptera \\
\hline \multicolumn{3}{|c|}{ Cladistic approach based on morphology } \\
\hline Whiting et al. (1997) & Morphological data extracted from literature & Sistergroup of Antliophora \\
\hline Hörnschemeyer (2002) & Wing articulation & Tentatively placed in a clade with Coleoptera and Neuropterida \\
\hline Beutel \& Gorb (2001) & naracters of adults and larvae including attachment structures & Sistergroup of Coleoptera (Coleopterida concept) \\
\hline Kukalová-Peck \& Lawrence (2004) & Wing base and wing venation & Sistergroup of Coleoptera \\
\hline Beutel \& Gorb (2006) & $\begin{array}{l}\text { aracters of adults and larvae including attachment structures, } \\
\text { Mantophasmatodea and some developmental features added }\end{array}$ & Sistergroup of remaining Holometabola \\
\hline
\end{tabular}

Friedrich \& Beutel (2010) 166 thoracic characters (30 holomatabolan terminals, 4 outgroups) $\quad$ Sistergroup of Coleoptera (Coleopterida concept)

Beutel et al. (2011) 356 characters of adults and larvae (same sampling as in previous study) Sistergroup of Coleoptera (Coleopterida concept)

\begin{tabular}{|c|c|c|}
\hline \multicolumn{3}{|c|}{ Single gene analyses } \\
\hline Chalwatzis et al. (1996) & 18S rRNA & Sistergroup of Diptera \\
\hline $\begin{array}{l}\text { Whiting et al. (1997) } \\
\qquad 18 \mathrm{~S},\end{array}$ & $\begin{array}{c}\text { 18S rRNA (alignement with MALIGN) } \\
\text { 28S rRNA (alignement with MALIGN) } \\
\mathrm{NA}+\text { morphological data extracted from literature (total evidence) }\end{array}$ & $\begin{array}{l}\text { Sistergroup of Diptera (Halteria concept) } \\
\text { Sistergroup of Diptera (Halteria concept) } \\
\text { Sistergroup of Diptera (Halteria concept) }\end{array}$ \\
\hline $\begin{array}{l}\text { Wheeler et al. (2001) } \\
\qquad 18 \mathrm{~S},\end{array}$ & $\begin{array}{c}\text { 18S rRNA (analysed with POY) } \\
\text { 28S rRNA (POY) } \\
\mathrm{NA}+\text { morphological data extracted from literature (total evidence) }\end{array}$ & $\begin{array}{l}\text { Sistergroup of Metajapyx (Diplura) } \\
\text { Sistergroup of Callinectes (Crustacea, Decapoda) } \\
\text { Sistergroup of Diptera (Halteria concept) }\end{array}$ \\
\hline Whiting (2002) & 18S rRNA (182 taxa, POY) & Sistergroup of Diptera (Halteria concept) \\
\hline Hayward et al. (2005) & USP/RXR (ecdysone receptor, Ultraspiracle proteins) & Not with Diptera \\
\hline Wiegmann et al. (2009) & 6 single copy nuclear genes & Sistergroup of Coleoptera (Coleopterida concept) \\
\hline McKenna \& Farrell (2010) & $\begin{array}{l}7 \text { single copy nuclear genes }+18 \mathrm{~S} \text { and } 28 \mathrm{~S} \text { rRNA } \\
7 \text { single copy nuclear genes }\end{array}$ & $\begin{array}{l}\text { Polyphaga (subordinate in Coleoptera) } \\
\text { Sistergroup of Neuropterida }\end{array}$ \\
\hline Ishiwata (2011) & $\begin{array}{l}\text { Catalytic subunit of DNA polymerase delta, } \\
2 \text { large subunits of RNA polymerase II }\end{array}$ & Sistergroup of Coleoptera (Coleopterida concept) \\
\hline
\end{tabular}

Cameron et al. (2009)

Niehuis et al. (2012)
Mitochondrial genomes

Entire genomes (Neuropterida not included)
Strepsiptera included but not mentioned

Sistergroup of Coleoptera (Coleopterida concept) (Neuropterida + Strepsiptera not completely excluded) 
obviously linked to a similar type of parasitism, and that adult features rather support a common ancestry of the two orders than a subordinate placement of Strepsiptera.

A classification appearing unorthodox from today's perspective was presented by K.E.A. Gerstaecker in Peters et al. (1863-1875: Handbuch der Zoologie, Vol. II), with a large ordo Neuroptera, which did not only included the three neuropterid orders but also a family Panorpina (Panorpa), and Strepsiptera and Trichoptera, both classified as a Zunft. He considered strepsipterans as most closely related to the trichopteran family Phryganeidae, based on the alleged presence of sac-like branchiform organs. These structures were erroneously ascribed to strepsipteran larvae by Newport (1851) as already pointed out by Schaum (1865) (see also Saunders, 1872).

\section{Later pre-Hennigian concepts}

In a detailed treatment of Strepsiptera with a focus on North American species, Bohart (1941) critically discusses earlier phyloge- netic hypothesis. He dismisses Pierce's arguments for the Pupariataconcept (Pierce, 1936) (see above), and also points out that many characters shared by Strepsiptera and Ripiphoridae are not in themselves of fundamental importance. He emphasizes that the presence of isomerous tarsi in Strepsiptera excludes a placement among the heteromerous groups of beetles (Tenebrionoidea) as for instance Ripiphoridae or Meloidae, and concludes that the order is closely allied to the Coleoptera.

In the mid-20 $0^{\text {th }}$ century a variation of Rossi's Hymenoptera concept resurfaced in the famous Traité de Zoologie (Jeannel, 1951) and a related original study (Jeannel, 1945). The prominent French entomologist and director of the Musée d'Histoire Naturelle (Paris) R. Jeannnel strongly criticized a placement of Strepsiptera close to or even within Coleoptera (Jeannel, 1951). Like Crampton (1931) he pointed out that the similarities with Ripiphoridae are superficial, and that the postabdominal segments of the $1^{\text {st }}$ instar larvae differ profoundly (e.g., terminal appendages). He emphasized numerous struc-

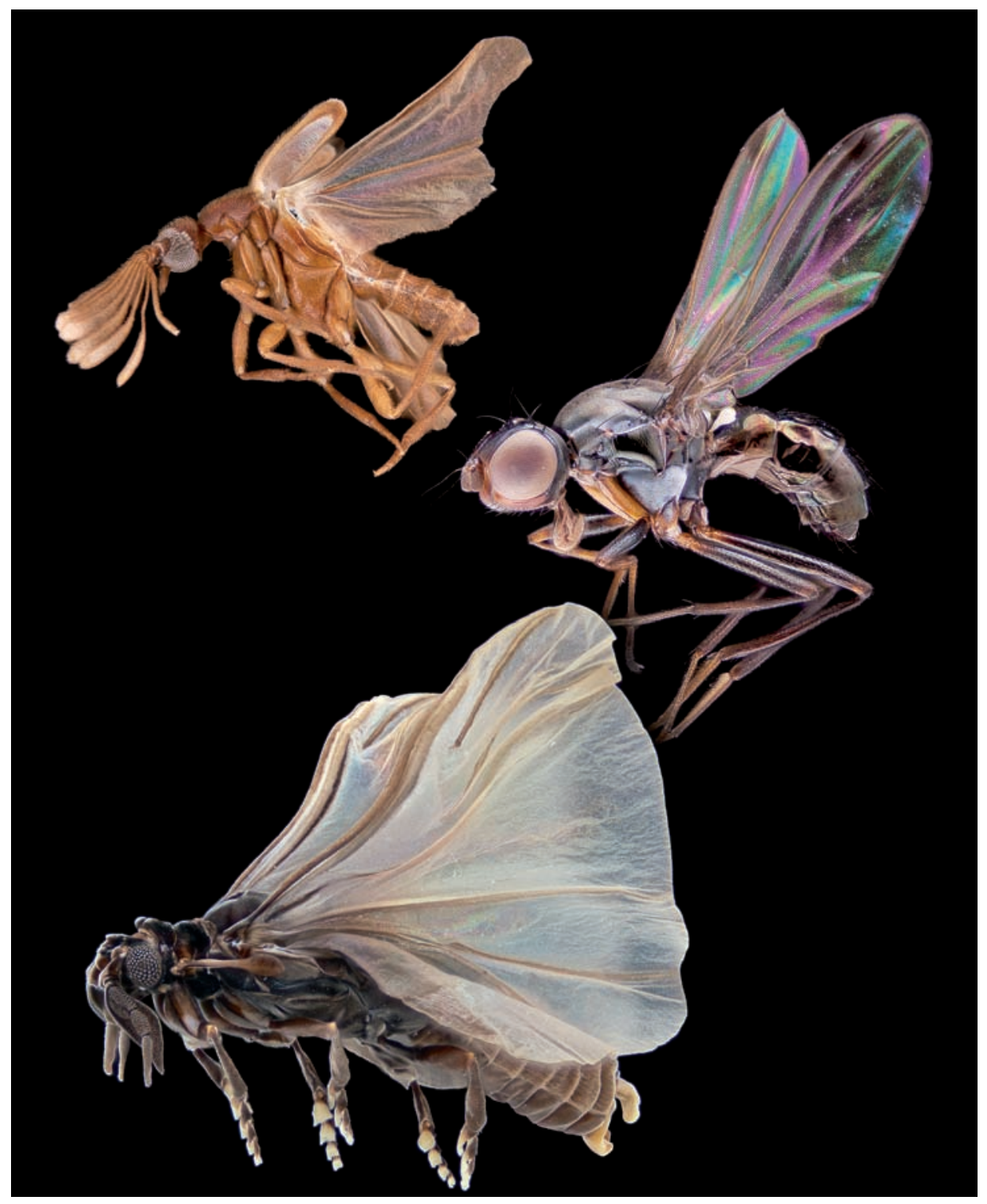

Figure 2. From top to bottom: Ripidius sp., male (Coleoptera, Ripiphoridae), length=3.1 mm; Sepsis fulgens (Diptera, Sepsidae), length $=3.3 \mathrm{~mm}$; Stylops ovinae, male (Strepsiptera, Stylopidae), length=4 $\mathrm{mm}$. 
tural affinities of strepsipteran males with members of basal hymenopteran lineages, such as for instance the orthognathous free head (tête libre), the distinctly reduced prothorax, the strongly developed basistarsus, and the assumed presence of numerous (vestigial) Malpighian tubules in secondary strepsipteran larvae. Jeannel (1951) assigned ordinal rank to Strepsiptera, but implicitly suggested a subordinate placement in Hymenoptera (...détache d'une ligne primitive...). His concept was flawed by an insufficiently detailed knowledge of strepsipteran morphology and his systematic approach based on similarity, as in earlier typological approaches. The listed structural affinities between Strepsiptera and symphytans are either plesiomorphic, not part of the strepsipteran groundplan, unspecific, or based on imprecise information available by that time.

The British scholar and entomologist R. A. Crowson was an outstanding figure in the investigation of Coleoptera in the $20^{\text {th }}$ century (e.g., Vickerman, 1995; Wegrzynowicz, 1995; Beutel et al., 2009). Crowson considered himself as a lifelong Darwinist and his phylogenetic concept was rather based on his Darwinian ideas and intuition, than on a consequent character analysis (Beutel et al., 2009).

Crowson was convinced that Strepsiptera are only a subordinate coleopteran lineage (Crowson, 1955, 1960, 1981). As features supporting affinities with Coleoptera he identified the structure of the metendosternite (metafurca), the stronger sclerotization of the abdominal sternites (compared to the tergites), the large metacoxa with a reduced motility, and the presence of a gula [at least in Mengenillopsis (=Mengenilla); Crowson, 1955]. In later studies these arguments were refuted or at least weakened. The metafurca in Coleoptera is extremely variable (e.g., Crowson, 1938, 1942; Balfour-Browne, 1961) and features shared by Strepsiptera and some representatives of Coleoptera are unspecific, the stronger sclerotization of the sternites is not a groundplan feature of Strepsiptera (Pohl et al., 2005), and an identifiable gula is absent in all know adult strepsipterans (e.g., Beutel \& Pohl, 2006b). The condition of the metacoxa could be synapomorphic. However, the structural affinities are also unspecific.

Crowson $(1955,1960)$ justified a placement within the suborder Polyphaga with the reduction of one leg segment in the $1^{\text {st }}$ instar larva, and the absence of the notopleural suture in adults. He treated Strepsiptera as an independent superfamily in this megadiverse beetle suborder. However, it is evident today that the modification of the larval legs are non-homologous (e.g., Pohl, 2000) and the condition of the prothorax is profoundly different in Strepsiptera (Koeth et al., 2012) and Polyphaga [e.g., Hlavac, 1973 (cryptopleura); Ge et al., 2007]. The placement in the polyphagan subgroup Symphiogastra (Eucinetoidea, Elateriformia, Cucujiformia) (Crowson, 1955) was based on the lack of articulated larval urogomphi. This implies that these structures were present in strepsipteran ancestors, which appears unlikely considering the presence of other terminal abdominal appendages (Pohl, 2000). Moreover, a reduction of movable urogomphi has obviously taken place several times in Coleoptera (e.g., Myxophaga, Trachypachidae) (Beutel \& Haas, 2000). Finally, the lack of abdominal spiracles VIII was used as an argument for an assignment to the cucujform series. In contrast to this placement it was already emphasized by Hennig (1969) that Strepsiptera lack cryptonephric Malpighian tubules, an autapomorphy of Cucujiformia (e.g., Beutel \& Haas, 2000).

Crowson (1955) pointed out affinities of strepsipteran primary larvae with those of the tenebrionoid families Meloidae and Ripiphoridae. Both coleopteran groups are characterized by hypermetamorphosis like Strepsiptera and larvae of Ripiphoridae are endoparasitic. The striking similarity with some adult ripiphorids (e.g., flabellate antennae) was also recognized by Crowson (1955). Nevertheless, he correctly pointed out that a close relationship with these lineages is unlikely as strepsipteran males have a tarsal formula of 5-5-5 (groundplan) whereas Tenebrionoidea are characterized by a formula 5-5-4 (Heteromera).
In his comprehensive work on The Biology of Coleoptera Crowson (1981) suggested a close relationship with the highly specialized woodassociated cucujiform family Lymexylidae. He combined both groups in a cucujiform superfamily Lymexyloidea. The lymexylid genus Atractocerus was already compared with Strepsiptera earlier (see e.g., Schaum 1865) due to its highly aberrant morphology (King, 1955; Pix et al., 1993: functional halteres). However, it is evident that many features displayed by this genus are absent in the lymexylid groundplan.

Ross (1965) also supported a status as a subordinate coleopteran group and a placement in the series Cucujiformia. He pointed out that the reduced wings, the triungulin larva, the reduced wing venation, and the parasitic life style suggest a close relationship with the tenebrionoid family Meloidae. However, the similarities in the morphology and development are superficial at best. Strepsipteran primary larvae differ strongly from all meloid larvae (e.g., Ge et al., 2012) and aside from this it is inappropriate to refer to them as triungulins (e.g., Pohl, 2000).

In his last study published more than five decades after his first contribution on Strepsiptera Pierce (1964) vehemently argued against a close relationship with Coleoptera, especially a subordinate placement in Cucujiformia. This reaction was apparently inspired by the inclusion of Strepsiptera in Coleoptera in R. Arnetts Beetles of the United States (Arnett, 1963). While most of his arguments referring to a subordinate polyphagan placement are conclusive, the differences between beetles and strepsipterans he listed are definitely not in conflict with a sistergroup relationship between both orders.

\section{The Hennigian period}

The German dipterist W. Hennig not only revolutionized systematic methods in the middle of the last century (Hennig, 1950, 1966) but also placed insect systematics on a sound scientific basis in his groundbreaking work Die Stammesgeschichte der Insekten (Hennig, 1969) (see e.g., Beutel et al., 2009).

Hennig emphasized the uncertainty of the phylogenetic placement of Strepsiptera. He thoroughly discussed the possible relationships of the group, implicitly favoring a sistergroup relationship with monopyhletic Coeloptera (Hennig, 1969: fig. 95).

An outstanding figure in the investigation of Strepsiptera was $R$. Kinzelbach, who tremendously increased the morphological knowledge of the group (e.g., Kinzelbach, 1967, 1971a; Kinzelbach \& Pohl, 1994; Pohl et al., 2005). In his $\mathrm{PhD}$ thesis on adult strepsipteran head structures Kinzelbach (1967) tentatively considered a close relationship with the Mecopterida (Mecopteroidkomplex), especially with Trichoptera and Lepidoptera (Zeuglopteren und Lepidopteren). He listed several structural affinities (e.g., broadened head capsule, strongly convex compound eyes, processus subgenales), but discarded this working hypothesis in his comprehensive study published few years later (Kinzelbach, 1971a). In this work he listed three remaining serious options, i) a subordinate placement within Coleoptera (e.g., Crowson, 1955), ii) a sistergroup relationship with monophyletic beetles (e.g., Ulrich, 1943), and iii) an early branch distantly related to Neuropterida.

An informal evaluation of characters of the wing base and wing venation was presented by Kukalová-Peck \& Lawrence (1993). The authors suggested a clade Coleopterida including Strepsiptera and monophyletic Coleoptera based on six potential wing apomorphies (or shared autapomorphic trends). Their interpretation of the strepsipteran wing venation was criticized by Whiting \& Kathirithamby (1995). However, this in turn was refuted by Kukalová-Peck \& Lawrence (2004).

The wing base of Holometabola was analyzed by Hörnschemeyer (2002). The author examined and discussed Strepsiptera but pointed out that no striking synapomorphies link strepsipterans with other groups of holometabolan insects.

A completely new option was discussed by the outstanding Danish entomologist N.P. Kristensen (1981, 1999), a position outside of Holometabola (or as sistergroup of all the remaining endopterygote lin- 
eages). He pointed out that in contrast to the typical holometabolous development compound eyes appear before the pupal stage (in secondary larvae) in Strepsiptera. His idea was later adopted by Beutel \& Pohl (2006a), who added that primary larvae of Strepsiptera possess eleven abdominal segments in contrast to all other holometabolan groups [except for Boreidae (Mecoptera); Beutel et al., 2011] and that the terminal bristles are likely cerci, which are otherwise missing in holometabolan larvae. An additional argument was the presence of external larval wing buds as distinct convexities, in contrast to the typical endopterygote condition, which is usually considered as an autapomorphy of Holometabola.

\section{Cladistic approaches based on morpholgy}

The first formal cladistic analysis of Holometabola was carried out by Whiting et al. (1997) in a study with a main focus on molecular data. The morphological characters, which were largely extracted from the literature (e.g., Kristensen, 1975, 1981, 1991, 1995; Boudreaux, 1979), yielded a placement of Strepsiptera not suggested before, as the sistergroup of a clade comprising Diptera, Siphonaptera and Mecoptera (Antliophora). However, the presumptive clade Strepsiptera+Antliophora was overruled by the total evidence analysis in the same study (see below).

The first cladistic treatment of the entire Hexapoda was published by Beutel \& Gorb (2001), a study mainly focused on the evolution of attachment structures, but based on a broad array of morphological features of different body regions and life stages. A sistergroup relationship between monophyletic Coleoptera and Strepsiptera was confirmed even though posteromotorism and the reduced size of the mesothorax were not included as apparently non-independent characters.

The matrix of Beutel \& Gorb (2001) was modified and re-analyzed in Beutel \& Gorb (2006). The order Mantophasmatodea described in 2002 (Klass et al., 2002) was included and several characters of the postembryonic development. The analysis resulted in a different placement of Strepsiptera, as the sistergroup of all the remaining holometabolan orders as discussed by Kristensen (1999) and Beutel \& Pohl (2006a). The monophyly of Holometabola excl. Strepsiptera was supported by the features listed above, i.e. the first appearance of compound eyes in the pupal stage, the complete absence of external wing buds in larvae, the absence of the larval abdominal segment XI, and the absence of larval cerci (Beutel \& Gorb, 2006).

In a study based on 126 thoracic features and 34 terminal taxa (Goodbye Halteria?) Friedrich \& Beutel (2010) analyzed the relationships of the holometabolan orders. In the two minimum length trees Strepsiptera were placed as sistergroup of Coleoptera (branch support value 8) like in Beutel \& Gorb (2001), but in this case mainly supported by features linked to posteromotorism. An extensive data matrix comprising 356 characters of different life stages and body parts was analyzed by Beutel et al. (2011) with the same taxon sampling. The parsimony analysis (1 single tree) and Bayesian inference both unambiguously supported a clade Strepsiptera+Coleoptera, with a branch support value of 6 in the most parsimonious tree.

\section{Molecular approaches: single gene analyses}

The use of molecular data and especially of rRNA had a strong impact on the debate on the placement of Strepsiptera. That 18S rRNA sequences support a sistergroup relationship between Strepsiptera and Diptera was published in a short note by Whiting \& Wheeler (1994), but without presenting data and any details of the analyses. This gene, which played a major role in the first two decades of molecular systematics, was also analyzed in a study of Chalwatzis et al. (1996) (between 1809 and 3316 bp). The sampling comprised 12 holometabolan species and 7 outgroup taxa. The analyses (neighbor-joining and maximum parsimony) yielded a clade Strepsiptera+Diptera as suggested by Whiting \& Wheeler (1994).

Different placements of Strepsiptera were suggested by analysis of molecular and morphological data in Whiting et al. (1997). Strepsiptera were placed as sistergroup of Diptera in the 18S and 28S rRNA trees, and also in the trees based on both genes combined and in the total evidence analyses (strict consensus trees). This revived hypothesis of dipteran affinities (e.g., Lamarck, 1816) became known as the Halteria concept, referring to the presence of similar halteres, drumstickshaped gyroscopic sense organs (Ulrich, 1930; Pix et al., 1993), on the mesothorax or metathorax, respectively. The proponents of a sistergroup relationship between Strepsiptera and Diptera argued that the insertion of the halteres on different segments may be due to a shift in the homeotic gene cluster (Whiting \& Wheeler, 1994), but did not present specific evidence supporting such a scenario.

Interestingly the results differed in analyses based on the same genes and a similar morphological data set conducted few years later (Wheeler et al., 2001). The morphological tree also showed a sistergroup relationship with Antliophora and the $18 \mathrm{~S}$ tree a clade Halteria. However, Strepsiptera were placed as the sistergroup of the primary wingless Metajapyx (Diplura) or even outside of Hexapoda in the $18 \mathrm{~S}$ and $28 \mathrm{~S}$ trees, respectively (Wheeler et al., 2001: figs 13, 14). In contrast to Whiting et al. (1997) the analyses were carried out with POY by Wheeler et al. (2001), i.e. simultaneous alignment and parsimony analyses (e.g., Wheeler et al., 1996-2003).

A rather unusual attempt to clarify the position of Strepsiptera was undertaken by Bonneton et al. (2006). The authors analysed a heterodimer composed of two nuclear receptor proteins involved in the regulation of ecdysteroids - ECR (NR1H1) and ultraspiracle (USP/RXR; NR2B4). They showed that both ECR and USP/RXR ligand-binding domains experienced a strongly accelerated rate of evolution in Diptera and Lepidoptera, two orders assigned to a clade Mecopterida by Hinton (1958), Hennig (1969), Kristensen $(1975,1999)$ and others. As this systematic unit as defined by Hinton (1958) [see also Hennig (1969) and Kristensen $(1975,1999)]$ does not contain Strepsiptera, this was a valid argument against a sistergroup relationship between Strepsiptera and Diptera. However, the claim in title of the study (...that clarifies the Strepsiptera problem) was certainly an overstatement.

Wiegmann et al. (2009) analyzed 6 single copy nuclear genes with a sampling comprising representatives of all holometabolan orders. The results suggested a clade Coleopterida comprising Strepsiptera and Coleoptera with moderate support, but as only polyphagan terminals were included a subordinate placement of Strepsiptera in Coleoptera remained a possible option. A data set comprising 18 s and $28 \mathrm{~S}$ rRNA and 7 single-copy nuclear protein-coding genes was analysed by McKenna \& Farrell (2010). The results based on the 7 single-copy nuclear protein-coding genes supported a sistergroup relationship with Neuropterida. Interestingly the outcome was clearly different with the 9 genes included. This data set supported a concept similar to that of Crowson $(1955,1981)$, with Strepsiptera subordinate in Coleoptera. A close relationship with Coleoptera was also suggested by Longhorn et al. (2010). Using ribosomal proteins these authors rejected the Halteria hypotheses proposed by Whiting et al. (1997) and Wheeler et al. (2001).

Ishiwata et al. (2011) analysed the relationships within the entire Hexapoda based on three nuclear genes (catalytic subunit of DNA polymerase delta, 2 largest subunits of RNA polymerase II). Like in Wiegmann et al. (2009) the results supported an arrangement [(Coleoptera+Strepsiptera)+Neuropterida] and the Halteria concept was refuted by all statistical tests.

\section{The age of phylogenomics}

In a study of Cameron et al. (2009) entire mitochondrial genomes were analyzed with a fairly large taxon sampling including representatives of all orders except for Zoraptera. Interestingly, in the study Strepsiptera are not mentioned and cladograms are not shown. This suggests unorthodox and implausible placements in the analyses. 
The most recent approach to solve the Strepsiptera problem was conducted by Niehuis et al. (2012) based on entire genomes and transcriptomes. The analyses of the former data set yielded a sistergroup relationship between Strepsiptera and Coleoptera, but Neuropterida were not included and Coleoptera were only represented by the tenebrionoid Tribolium. In an analysis based on transcriptomes also including the archostematan beetle Priacma serrata LeConte the monophyly of beetles was clearly supported, thus excluding a subordinate placement of Strepsiptera within Polyphaga. The option of a sistergroup relationship with Neuropterida (McKenna \& Farrell, 2010) cannot be completely excluded yet. However, it was pointed out in Niehuis et al. (2012) that this is highly unlikely from a morphological perspective. An enforced clade Strepsiptera+Neuropterida would require more than 20 additional steps with the morphological data set of Beutel et al. (2011).

\section{Discussion}

The reasons for the prolonged uncertainties of placing Strepsiptera in the system of Hexdapoda are complex, even though the extremely modified morphology and biology stand out as the main factors. Like in molecular phylogenies with taxa with a highly accelerated substitution rate (e.g., 18S rRNA of Diptera and Strepsiptera) a reliable phylogenetic placement can be greatly impeded by numerous accumulated morphological apomorphies, in this case linked with a highly specialized biology. Reductions, for instance related to the loss or modification of wings, can lead to artifacts in phylogenetic analyses (Friedrich \& Beutel, 2010), and similar life styles, especially specialized types of parasitism, can result in misleading similar features in larval stages.

The early attempts to place Strepsiptera were affected by the typological approach, i.e. a subjective choice and interpretation of features considered as typical (e.g., Beutel et al., 2009). This explains easily why Strepsiptera bounced between Hymenoptera (parasitism), Ripiphoridae (similarity of primary larvae, hypermetamorphosis, some features of adults of some members of Ripiphoridae), or Diptera (halteres), or were even placed in a completely artificial unit Pupariata (Pierce, 1936).

Crowson $(1955,1960,1981)$ attempts to place Strepsiptera were flawed by the lack of a consequent phylogenetic methodology. He was familiar with Hennigian and cladistic principles and methods but remained deeply skeptical [Crowson, 1991 (A critique of current cladistics); see also Beutel et al., 2009]. In the light of current phylogenetic approaches and results his hypothesis of a subordinate placement within Cucujiformia is untenable. His cucujiform superfamily uniting Strepsiptera with Lymexylidae is not supported by any synapomorphic feature. Moreover, it was shown in Friedrich \& Beutel (2010) and Beutel et al. (2011) that Coleoptera and also Coleoptera excl. Archostemata (both excluding Strepsiptera!) are well supported as monophyletic lineages.

The investigation of strepsipteran relationships became more focused with the use of the clearly defined Hennigian concepts of monophyly, synapomorphy and groundplan (Hennig, 1950, 1966; see also Beutel et al., 2009). The informal (non-numerical) character evaluations tended to suggest a sistergroup relationship between Strepsiptera and monophyletic Coleoptera, but uncertainties were pointed out in all studies (see e.g., Kinzelbach, 1971a; Hennig, 1969; Kristensen, 1981, 1999). Phylogenetic signals are obscured by numerous strepsipteran autapomorphies in all life stages and were apparently largely eroded in the long evolutionary history of the order. The only obvious character suggesting a possible common origin of Strepsiptera and Coleoptera was the posteromotorism with related features such as the increased size of the metathorax or the loss of mesothoracic muscles.

The intriguing scenario with Strepsiptera as non-holometabolan group (or sistergroup of the remaining Holometabola) (Kristensen, 1981, 1999; Beutel \& Pohl, 2006a) was confirmed in a cladistic analysis of Beutel \& Gorb (2006) but not in later studies based on more extensive morphological or molecular data sets (e.g., Wiegmann et al., 2009; McKenna \& Farrell, 2010; Beutel et al., 2011; Niehuis et al., 2012). This underlines that analyses based on limited character sets (and taxon samplings) can lead to erroneous results. Seemingly plesiomorphic developmental features of Strepsiptera are likely due to reversals (Niehuis et al., 2012).

The early molecular investigations on strepsipteran interrelationships triggered an intensive discussion on a phenomenon called long-branchattraction [Huelsenbeck, 1997 (Is the Felsenstein zone a fly trap)]; see also Felsenstein, 1978]. It was pointed out by Carmean \& Crespi (1995) that Strepsiptera and Diptera share a strongly accelerated substitution rate in 18S rRNA which may have caused an artificial attraction of the two branches. The long-branch effect (Felsenstein zone) mainly affects parsimony analyses and it was shown by Huelsenbeck (1997) that the 18S data analysed by Carmean \& Crespi (1995) support a clade Strepsiptera+Coleoptera when maximum likelihood (ML) was used instead of maximum parsimony (MP). Huelsenbeck (1998) re-evaluated the data of Whiting et al. (1997) (1.0 KB of 18S rRNA for 85 terminal taxa, $0.4 \mathrm{~KB}$ of $28 \mathrm{~S}$ rRNA for 51 terminal taxa) with different analytical methods (MP, ML, neighbour-joining, Monte Carlo simulation) and concluded that neither the monophyly nor the non-monophyly of Strepsiptera+Diptera is strongly supported. Similarly, Bayesian analyses of the data did not lead to conclusive results. Huelsenbeck et al. (2001) pointed out that the placement of Strepsiptera remains uncertain and that more sequence data from other genes are required.

The Halteria concept was already questioned by Rokas et al. (1999) based on a different approach. These authors showed that an intron insertion in the engrailed gene of the homeobox cluster is missing in a strepsipteran species (Stichotrema dallatorreanum) but is present in representatives of Mecopterida belonging to the orders Diptera and Lepidoptera.

Wheeler et al. (2001) is an interesting case study and played an important role in the investigation of hexapod phylogenetics. All three analyzed data sets yielded different results. It was pointed out in earlier studies that the literature-based morphological character set contained some problematic codings and the sistergroup relationship with Antliophora obviously did not reflect the true position of Strepsiptera. The $28 \mathrm{~S}$ tree was totally in conflict with all older and current concepts, with many orders paraphyletic and a very unrealistic placement of Strepsiptera outside of Hexapoda, whereas the $18 \mathrm{~S}$ tree finally yielded a clade Metajapyx (Diplura) + Strepsiptera. To construct a phylogenetic hypothesis (summary tree on p. of Wheeler et al., 2001) using a combination of obviously conflicting and problematic data sets is questionable from a theoretical point of view. Moreover, the analyses with POY may have had a negative aspect. This is suggested by comparisons of the trees based on 28S rRNA in Whiting et al. (1997) with Strepsiptera placed in Holometabola, versus a highly unorthodox position outside of Pterygota in Wheeler et al. (2001). POY was criticized by Kjer et al. (2007) from a theoretical perspective and it was demonstrated that it performs less well than other approaches by Ogden \& Rosenberg (2007).

The potential ambivalence of molecular data was demonstrated in McKenna \& Farrell (2010) with two incompatible placements, one reviving the subordinate coleopteran placement of Crowson (1955, 1960, 1981), and the other one a sistergroup relationship with Neuropterida, partly in agreement with Gerstaecker's obsolete classification.

The most recent study based on entire genomes (and transcriptomes) strongly supports a sistergroup relationship with monophyletic Coleoptera. A sistergroup relationship with Neuropterida remains a theoretical option as members of this group were not included. However, this placement is highly unlikely from a morphological perspective (Beutel et al., 2011; Niehuis et al., 2012). 
After more than 200 years the phylogenetic Odyssey of Strepsiptera almost came to an end. Problems were mainly caused by the extreme degree of specialization and a related accumulation of numerous autapomorphies. A progressive approximation towards a solution was made possible by improved morphological and molecular data sets and refined methods of phylogenetic reconstruction. Results from the international 1KITE project, which is aiming at analyses of transcriptomes of 1000 selected hexapod species (www.1KITE.org/), are not available yet. However, preliminary analyses (B. Misof and K. Meusemann, pers. comm.) support a clade Coleopterida with monophyletic beetles as suggested by Hennig (1969), Kinzelbach (1971a, b), Kathirithamby (1991), Willmann (2005), Wiegmann et al. (2009), Beutel et al. (2011) and Niehuis et al. (2012).

\section{References}

ARNETT R.H., 1963 - The Beetles of the United States (a Manual for Identification). - Catholic University of America Press, Washington D.C., USA.

BALFOUR-BROWNE F., 1961 - The metendosternite in the Coleoptera. J. Linn. Soc. London 44 (298): 337-354.

BEUTEL R.G., HAAS F., 2000 - Phylogenetic relationships of the suborders of Coleoptera (Insecta). - Cladistics 16: 1-39.

BEUTEL R.G., LESCHEN R.A.B., FRIEDRICH F., 2009 - Darwin, beetles and phylogenetics. - Naturwiss. 96: 1293-1312.

BEUTEL R.G., FRIEDRICH F., HÖRNSCHEMEYER T., POHL H., HÜNEFELD F., BECKMANN F., MEIER R., MISOF B., WHITING M.F., VILHEMSEN L., 2011 - Morphological and molecular evidence converging upon a robust phylogeny of the megadiverse Holometabola. - Cladistics 27: 341-355.

BEUTEL R.G., POHL H., 2006a - Endopterygote systematics - where do we stand and what is the goal (Hexapoda, Arthropoda). - Syst. Entomol. 31: 202-219.

BEUTEL R.G., POHL H., 2006b - Head structures of males of Strepsiptera (Hexapoda) with emphasis on basal splitting events within the Order. - J. Morph. 267: 536-554.

BEUTEL R.G., POHL H., HÜNEFELD F., 2005 - Strepsipteran brains and effects of miniaturisation. - Arthr. Str. Dev. 34: 301-313.

BEUTEL R.G., GORB S., 2001 - Ultrastructure of attachment specializations of hexapods (Arthropoda): evolutionary patterns inferred from a revised ordinal phylogeny. - J. Zool. Syst. Evolut. Res. 39: 177-207.

BEUTEL R.G., GORB S., 2006 - A revised interpretation of the evolution of attachment structures in Hexapoda (Arthropoda), with special emphasis on Mantophasmatodea. - Arthr. Syst. Phyl. 64 (1): 3-25.

BOERNER C., 1904 - Zur Systematik der Hexapoda (Strepsiptera). Zool. Anz. 27: 511-533.

BOHART R.M., 1941 - A revision of the Strepsiptera with special reference to the species of North America. - Univ. Calif. Publ. Entomol. 7 (6): 91-160.

BONNETON F., BRUNET F.G., KATHIRITHAMBY J., LAUDET V., 2006 The rapid divergence of the ecdysone receptor is a synapomorphy for Mecopterida that clarifies the Strepsiptera problem. - Ins. Mol. Biol. 15 (3): 351-362.

BOUDREAUX H.B., 1979 - Arthropod phylogeny. - John Wiley \& Sons, New York.

BRAVO F., POHL H., NETO A., BEUTEL R.G., 2009 - Bahiaxenidae, a living fossil and a new family of Strepsiptera (Hexapoda) discovered in Brazil. - Cladistics 25: 614-623.

BURMEISTER H., 1837 - Handbuch der Naturgeschichte. Zum Gebrauch bei Vorlesungen. - Enslin, Berlin.

CAMERON S.L., SULLIVAN J., SONG H., MILLER K.B., WHITING F.W.,
2009 - A mitochondrial genome phylogeny of the Neuropterida (lace-wings, alderflies and snakeflies) and their relationship to the other holometabolous insect orders. - Zool. Scr. 38: 575-590.

CARMEAN C., CRESPI B.J., 1995 - Do long branches attract flies? Nature 373: 666.

CHALWATZIS N., HAUF J., VAN DE PEER Y., KINZELBACH R., ZIMMERMANN F.K., 1996 - 18S ribosomal RNA genes of insects: Primary structure of the genes and molecular phylogeny of the Holometabola. - Annls. Entomol. Soc. Am. 89: 788-803.

CRAMPTON G.C., 1931 - A phylogenetic study of the posterior metathoracic and basal abdominal structures of insects, with particular reference to the Holometabola. - J.N.Y. Entomol. Soc. 39 (3): 323-357.

CROWSON R.A., 1938 - The metendosternite of Coleoptera: a comparative study. - Trans. R. Entomol. Soc. London 87 (17): 397-416, 13 pls.

CROWSON R.A., 1942 - Further studies on the metendosternite in Coleoptera. - Trans. R. Entomol. Soc. London 94 (2): 273-310, 10 pls.

CROWSON R.A, 1955 - The Natural Classification of the Families of Coleoptera. Nathaniel Lloyd, London.

CROWSON R.A., 1960 - The phylogeny of Coleoptera. - Ann. Rev. Entomol. 5: 111-134.

CROWSON R.A., 1981 - The Biology of the Coleoptera. - Academic Press, New York.

CROWSON R.A, 1991 - A critique of current cladistics. - J. Nat. Hist. 25: 3-5.

CVAČKA J., JIROŠ P., KALINOVÁ B., STRAKA J., ČERNÁ K., ŠEBESTA P., TOMČALA A., VAŠÍČKOVÁ S., JAHN U., ŠOBOTNÍK J. 2012 Stylopsal: the first identified female-produced sex pheromone of Strepsiptera. - J. Chem. Ecol. 38: 1483-1491.

FELSENSTEIN J., 1978 - Cases in which parsimony or compatibility methods will be positively misleading. - Syst. Zool. 27: 401-410.

FRIEDRICH F., BEUTEL R.G., 2010 - Goodbye Halteria? The thoracic morphology of Endopterygota (Insecta) and its phylogenetic implications. - Cladistics 26: 579-612.

GE S.Q., BEUTEL R.G., YANG X.K., 2007 - Thoracic morphology of adults of Derodontidae and Nosodendridae and its phylogenetic implications (Coleoptera). - Syst. Entomol. 32: 635-667.

GE S.Q., WIPFLER B., POHL H., HUA Y., ŚLIPIŃSKI S.A., YANG X.K., BEUTEL R.G., 2012 - The first complete 3D reconstruction of a Spanish Fly primary larva (Lytta vesicatoria, Meloidae, Coleoptera). - PLoS ONE 7 (12): e52511.

GRANDI G., 1936 - Morphologia ed etologia comparate di insetti a regime specializaro, part 12: Macrosiagon ferrugineum flabellatum (F.). - Bollettino del Laboratorio di entomologia del R. Istituto superiore agrario di Bologna 9: 33-64.

GRIMALDI D., KATHIRITHAMBY J., SCHAWAROCH V., 2005 Strepsiptera and triungula in Cretaceous amber. - Ins. Syst. Evol. 36: 1-20.

HANDLIRSCH A., 1903 - Zur Phylogenie der Hexapoden. - Sitzungsber. Akad. Wiss. Wien 113: 716-738.

HAYWARD D.C., TRUEMAN J.W.H., BASTIANI M.J., BALL E.E., 2005 The structure of the USP/RXR of Xenos pecki indicates that Strepsiptera are not closely related to Diptera. - Dev. Gen. Evol. 215: 213-219.

HENNIG W., 1950 - Grundzüge einer Theorie der Phylogenetischen Systematik. - Deutscher Zentralverlag, Berlin.

HENNIG W., 1966 - Phylogenetic Systematics. - University of Illinois Press, Urbana.

HENNIG W., 1969 - Die Stammesgeschichte der Insekten. - Verlag von Waldemar Kramer, Frankfurt a.M.

HINTON H.E., 1958 - The phylogeny of the panorpoid orders. - Ann. Rev. Entomol. 3: 181-206.

HLAVAC T.F., 1973 - The prothorax of Coleoptera: origin, major features of variation. - Psyche 79: 123-149.

HÖRNSCHEMEYER T., 2002 - Phylogenetic significance of the wingbase of the Holometabola. - Zool. Scr. 31 (1): 17-29. 
HUELSENBECK J.P., 1997 - Is the Felsenstein zone a fly trap? - Syst. Biol. 46 (1): 69-74.

HUELSENBECK J.P., 1998 - Systematic bias in phylogenetic analysis: is the Strepsiptera problem solved? - Syst. Biol. 47 (3): 519-537.

HUELSENBECK J.P., 2001- A Bayesian perspective of the Strepsiptera problem. - Tidjschr. Entomol. 144: 165-178.

HÜNEFELD F., BEUTEL R.G., 2005 - The sperm pumps of Strepsiptera and Antliophora (Hexapoda). - J. Zool. Syst. Evolut. Res. 43 (4): 297-306.

HÜNEFELD F., POHL H., WIPFLER B., BECKMANN F., BEUTEL R.G., 2011 - The male postabdomen and genital apparatus of Mengea tertiaria, a strepsipteran amber fossil (Insecta). - J. Zool. Syst. Evolut. Res. 49 (4): 298-308.

ISHIWATA K., SASAKI G., OGAWA J., MIYATA T., SU Z.H., 2011. Phylogenetic relationships among insect orders based on three nuclear protein-coding gene sequences. - Mol. Phyl. Evol. 58 (2): 169-180.

JEANNEL R., 1945 - Sur la position systématique des Strepsiptères. Rev. Fr. Entomol. 11 (3): 111-118.

JEANNEL R., 1951 - Ordre des Strepsiptères. Strepsiptera Kirby 1913; Rhipidioptera Lamarck 1916; Rhipiptera Latreille 1817. In: GRASSÉ P.P. (ed). Traité de Zoologie, Tome X, Fascicule II. Masson et Cie Éditeurs, Paris: pp. 1277-1299.

JOHNSTON J.S., ROSS L.D., BEANI L., HUGHES D.P., KATHIRITHAMBY J., 2004 - Tiny genomes and endoreduplication in Strepsiptera. Ins. Mol. Biol. 13 (6): 581-585.

KATHIRITHAMBY J., 1989 - Review of the order Strepsiptera. - Syst. Entomol. 14: 41-92.

KATHIRITHAMBY J., 1991. Strepsiptera. In: NAUMANN I.D., CARNE P.B., LAWRENCE J.F., NIELSEN E.S., SPRADBERRY J.P., TAYLOR R.W., WHITTEN M.J., LITTLEJOHN M.J. (eds). The Insects of Australia: a Textbook for Students and Research Workers. 2nd ed. CSIR0, Melbourne Univ. Press, Melbourne: pp. 684-695.

KATHIRITHAMBY J., 2009 - Host-parasitoid associations in Strepsiptera. - Ann. Rev. Entomol. 54: 227-249.

KATHIRITHAMBY J, GRIMALDI D, 1993 - Remarkable stasis in some lower tertiary parasitoids: descriptions, new records, and review of Strepsiptera in the Oligo-Miocene amber of the Dominican Republic. - Entomol. Scand. 24 (1): 31-41.

KING E.W., 1955 - The phylogenetic position of Atractocerus. - Coleopt. Bull. 9: 65-74.

KINZELBACH R.K., 1967 - Zur Kopfmorphologie der Fächerflügler (Strepsiptera, Insecta). - Zool. Jb. Anat. 84 (4): 559-684.

KINZELBACH R.K., 1971a - Morphologische Befunde an Fächerflüglern und ihre phylogenetische Bedeutung (Insecta: Strepsiptera). Schweizerbart'sche Verlagsbuchhandlung, Stuttgart.

KINZELBACH R.K, 1971b - Strepsiptera (Fächerflügler). Handbuch der Zoologie. De Gruyter, Berlin: pp. 1-68.

KINZELBACH R.K, 1978 - Fächerflügler (Strepsiptera). Gustav Fischer, Jena.

KINZELBACH R.K, 1990 - The systematic position of Strepsiptera (Insecta). - Amer. Entomol. 35: 291-30.

KINZELBACH R., POHL H., 1994 - The fossil Strepsiptera (Insecta: Strepsiptera). - Annls. Entomol. Soc. Amer. 87 (1): 59-70.

KIRBY W., 1802 - Monographia Apium Angliae - 1: 257-258, 2: 110-114.

KIRBY W., 1815 - VI. Strepsiptera, a new Order of Insects proposed; and the characters of the Order, with those of its genera, laid down. Trans. Linn. Soc. London 11(1): 86-122.

KJER K.M., GILLESPIE J.J., OBER K.A., 2007 - Opinions on multiple sequence alignment, and an empirical comparison of repeatability and accuracy between POY and structural alignments. - Syst. Biol. 56 (2):133-146.

KLASS K-D., ZOMPRO 0., KRISTENSEN N.P., ADIS J., 2002 Mantophasmatodea: a new insect order with extant members in the Afrotropics. - Science 296: 1456-1459.
KOETH M., FRIEDRICH F., POHL H., BEUTEL R.G., 2012 - The thoracic skeleto-muscular system of Mengenilla (Strepsiptera: Mengenillidae) and its phylogenetic implications. - Arthr. Str. Dev. 41 (4): 323-335.

KRISTENSEN N.P., 1975 - The phylogeny of hexapod orders. A critical review of recent accounts. - Z. zool. Syst. Evolut. Forsch. 13: 1-44.

KRISTENSEN N.P., 1981 - Phylogeny of insect orders. - Ann. Rev. Entomol. 26: 135-157.

KRISTENSEN N.P., 1991 - Phylogeny of extant hexapods. - In: NAUMANN I.D., CARNE P.B., LAWRENCE J.F., NIELSEN E.S., SPRADBERRY J.P., TAYLOR R.W., WHITTEN M.J., LITTLEJOHN M.J. (eds). The insects of Australia: a Textbook for Students and Research Workers. 2nd ed. CSIR0, Melbourne Univ. Press, Melbourne: pp. 125-140.

KRISTENSEN N.P., 1995 - Forty years' insect phylogenetics systematics. - Zool. Beitr. N.F. 36: 83-124

KRISTENSEN N.P., 1999 - Phylogeny of endopterygote insects, the most successful lineage of living organisms. - Europ. J. Entomol. 96: 237253.

KUKALOVA-PECK J., LAWRENCE J.F., 1993 - Evolution of the hind wing in Coleoptera. - Can. Entomol. 125: 181-258.

KUKALOVA-PECK J., LAWRENCE J.F., 2004 - Use of hind wing characters in assessing relationships among Coleopteran Suborders and major endoneopteran lineages. - Eur. J. Entomol. 101: 95-144.

LAMARCK J.B., 1816 - Histoire Naturelle des Animaux sans Vertèbres. III (Insecta). - Paris. pp 235-586.

LATREILLE P.A., 1809 - Genera crustaceorum et insectorum secundum ordinem naturalem in familias disposita, iconibus exemplisque plurimis explicata. Vol 4. Amand Koenig, Paris.

LATREILLE P.A., 1817 - Les crustacés, les arachnides et les insectes. In: CUVIER G. (ed). Le Règne Animal Distributè d'après son Organisation. Vol. 3. Deterville, Paris.

LAWRENCE J.F., NEWTON A.F., 1995 - Families and subfamilies of Coleoptera (with selected genera, notes, references and data on family-group names). In: PAKALUK J., ŚLIPIŃSKI S.A., (eds). Biology, Phylogeny, and Classification of Coleoptera: Papers celebrating the $80^{\text {th }}$ Birthday of Roy Crowson. Muzeum i Instytut Zoologii PAN, Warszawa, pp. 779-1006.

LONGHORN S.J., POHL H.W., VOGLER A.P., 2010 - Ribosomal protein genes of holometabolan insects reject the Halteria, instead revealing a close affinity of Strepsiptera with Coleoptera. - Mol. Phyl. Evol. 55 (3): 846-859.

MCKENNA D.D., FARRELL B.D., 2010 - 9-genes reinforce the phylogeny of holometabola and yield alternate views on the phylogenetic placement of Strepsiptera. - PLoS ONE 5 (7): e11887.

MCMAHON D.P., HAYWARD A., KATHIRITHAMBY J., 2011 - The first molecular phylogeny of Strepsiptera (Insecta) reveals an early burst of molecular evolution correlated with the transition to endoparasitism. - PLoS ONE 6 (6): e21206.

NEWMAN E.D., 1834 - Attempted division of British insects into natural orders. - Entomol. Mag. 2: 379-431.

NEWPORT G., 1851 - XVII. The natural history, anatomy, and development of Meloë and its affinities, compared with those of the Strepsiptera and Anoplura, with reference to the connection which exists between structure, function, and instinct. - Trans. Linn. Soc. London 20: 321-357.

NIEHUIS 0., HARTIG G., GRATH S., POHL H., LEHMANN J., TAFER H., DONATH A., KRAUSS V., EISENHARDT C., HERTEL J., PETERSEN M., MAYER C., MEUSEMANN K., PETERS R.S., STADLER P.F., BEUTEL R.G., BORNBERG-BAUER E., MCKENNA D.D., MISOF B., 2012 - Genomic and morphological evidence converge to resolve the enigma of Strepsiptera. - Curr. Biol. 22 (14): 1309-1313.

OGDEN T.H., ROSENBERG M.S., 2007 - Alignment and topological accuracy of the direct optimization approach via POY and traditional 
phylogenetics via ClustalW+PAUP*. - Syst. Biol. 56 (2): 182-193.

OSSWALD J., POHL H., BEUTEL R.G. 2009 - Extremely miniaturised and highly complex: The thoracic morphology of the first instar larva of Mengenilla chobauti (Insecta, Strepsiptera). - Arthr. Str. Dev. 39 (4): 287-304

PETERS W.C.H., CARUS J.V., GERSTÄCKER K.E.A. 1863-1875. Handbuch der Zoologie, Vol. 2, Arthropoden. Verlag von Wilhelm Engelmann, Leipzig.

PIERCE W.D., 1909 - A monographic revision of the twisted winged insects comprising the order Strepsiptera Kirby. - Bull. US Nat. Mus. 66: 1-232.

PIERCE W.D., 1918 - The comparative morphology of the order Strepsiptera together with records and descriptions of insects. Proc. US Nat. Mus. 54 (2242): 391-501.

PIERCE W.D., 1936 - The position of the Strepsiptera on the classification of insects. - Entomol. News 47 (10): 257-263.

PIERCE W.D., 1952 - A new Strepsipterous parasite of Membracidae. Bull. South. Calif. Acad. Sci. 51 (1): 4-8.

PIERCE W.D., 1964 - The Strepsiptera are a true order, unrelated to Coleoptera. - Annls. Entomol. Soc. Amer. 57: 603-605.

PIX W., NALBACH G., ZEIL J., 1993 - Strepsipteran forewings are haltere-like organs of equilibrium. - Naturwiss. 80: 371-374.

POHL H., 2000 - Die Primärlarven der Fächerflügler - evolutionäre Trends (Insecta, Strepsiptera). - Kaupia 10: 1-144.

POHL H., 2002 - Phylogeny of the Strepsiptera based on morphological data of the first instar larvae. - Zool. Scr. 31:123-138.

POHL H., 2009 - The oldest fossil strepsipteran larva (Insecta: Strepsiptera) from the Geisel Valley, Germany (Eocene). - Ins. Syst. Evol. 40 (4): 333-347.

POHL H., BEUTEL R.G., 2004 - Fine structure of adhesive devices of Strepsiptera (Insecta). - Arthr. Str. Dev. 33: 31-43.

POHL H, BEUTEL R.G., 2005 - The phylogeny of Strepsiptera (Hexapoda). - Cladistics 21: 1-47.

POHL H., BEUTEL R.G., 2008 - The evolution of Strepsiptera. - Zoology 111: 318-338.

POHL H., BEUTEL R.G., KINZELBACH R., 2005 - Protoxenidae fam. n. (Insecta, Strepsiptera) from Baltic amber - a missing link in strepsipteran phylogeny. - Zool. Scr. 31 (1): 123-134.

POHL H., WIPFLER B., GRIMALDI D., BECKMANN F., BEUTEL R.G., 2010 - Reconstructing the anatomy of the 42 million-year-old fossil Mengea tertiara (Insecta, Strepsiptera). - Naturwiss. 97: 855-859.

POHL H., NIEHUIS 0., GLOYNA K., MISOF B., BEUTEL R.G., 2012 - A new species of Mengenilla (Insecta, Strepsiptera) from Tunisia. ZooKeys 198: 79-101.

PROFFITT F., 2005. Twisted parasites from outer space perplex scientists. - Science 307 (5708): 343.

ROKAS A., KATHIRITHAMBY J., HOLLAND P.W.A., 1999 - Intron insertion as a phylogenetic character: the engrailed homeobox does not indicate affinity with Diptera. - Insect. Mol. Biol. 8: 527-530

ROSS H.H., 1965 - A Textbook of Entomology, 3rd edn. John Wiley \& Sons, New York.

ROSSIUS P., 1793 - Observation de M. Rossi sur un nouveau genre d'Insecte, voisin d'Ichneumons. - Bull. Soc. Philomat. 1: 49.

SAUNDERS S.S., 1872 - Stylopidarum, ordinem Strepsipterorum Kirbii constituentim, mihi tamen potium Coleoptorum Familiae, Rhipidoridis Meloidisque propinquae, Monographia. - Trans. Entomol. Soc. London 20: 1-49.

SCHAUM H., 1865 X. - On the systematic position of Strepsiptera. - J. Nat. Hist. 15 (85): 53-59.

SCHIØDTE J.M.C. 1862, 1883. De metamorphosi Eleutheratorum observationes: bidrag til insekternes udviklingshistorie. - Naturhist. Tidskr. (3), 1: 193-232, pls 1-10 (1862), 13:415-426, pl 18 (1863).
SHIPLEY A.E., 1904 - The orders of insects (Strepsiptera). - Zool. Anz. 27: 259-262.

SNODGRASS R.E., 1935 - Principles of insect morphology. - MacGrawHill, London.

TRAUTWEIN M.D., WIEGMANN B.M., BEUTEL R., KJER K., YEATES D.K., 2012 - Advances in insect phylogeny at the dawn of the postgenomic era. - Ann. Rev. Entomol. 57: 449-68.

TOLASCH T., KEHL S., DÖTTERL S., 2012 - First sex pheromone of the order Strepsiptera: (3R,5R,9R)-3,5,9-Trimethyldodecanal in Stylops melittae Kirby, 1802. - J. Chem. Ecol. 38: 1493-1503.

ULRICH W., 1927a - Strepsiptera, Fächerflügler. In: SCHULZE P., (ed). Biologie der Tiere Deutschlands 41: 1-103.

ULRICH W., 1927b - Über das bisher einzige Strepsipteron aus dem baltischen Bernstein und über eine Theorie der Mengeinenbiologie. - Z. Morph. Ökol. Tiere 8: 45-62.

ULRICH W., 1930 - Die Strepsipteren-Männchen als Insekten mit Halteren an Stelle der Vorderflügel. - Z. Morph. Ökol. Tiere 17: 552-624.

ULRICH W., 1943 - Die Mengeiden (Mengenillini) und die Phylogenie der Strepsipteren. - Z. Parasitenkde. 13: 62-101.

ULRICH W., 1956 - Unsere Strepsipteren-Arbeiten. - Zool. Beitr. NF 2: 177.

ULRICH W., 1966 - Evolution und System der Strepsipteren. - Int. Congr. Parasitol. Rome (1964), 609-611.

VICKERMAN K.,1995 - In praise of scholars - and one in particular: Roy Crowson. - In: PAKALUK J., ŚLIPIŃSKI S.A., (eds), Biology, Phylogeny, and Classification of Coleoptera: Papers celebrating the 80th Birthday of Roy Crowson. Muzeum i Instytut Zoologii PAN, Warszawa: 1-4.

WEBER H., 1933 - Lehrbuch der Entomologie. - Gustav Fischer, Jena.

WEGRZYNOWICZ P., 1995 - R.A. CROWSON - bibliography. In: PAKALUK J., ŚLIPIŃSKI S.A., (eds), Biology, Phylogeny, and Classification of Coleoptera: Papers celebrating the 80th Birthday of Roy Crowson. Muzeum i Instytut Zoologii PAN, Warszawa: 11-30.

WESTWOOD J.0., 1839 - XXXV. Observations upon the Strepsiptera. Trans. R. Entomol. Soc. London 2 (3): 169-172.

WHEELER W.C., GLADSTEIN D.S., DE LAET J. 1996-2003. POY. Version 3.0. ftp.amnh.org/pub/molecular/poy (current version 3.0.11). Documentation by JANIES D. and WHEELER W.C., Commandline documentation by DE LAET J and WHEELER WC.

WHEELER W.C., WHITING M., WHEELER Q.D., CARPENTER J.M., 2001 - The phylogeny of the extant hexapod orders. - Cladistics 17: 113169.

WHITING M.F, 2002 - Phylogeny of the holometabolous insect orders: molecular evidence. Zool. Scr. 31: 3-15.

WHITING M.F., KATHIRITHAMBY J., 1995 - Strepsiptera do not share hind wing venational synapomorphies with Coleoptera: a reply to Kukalova-Peck and Lawrence. - J. NY Entomol. Soc. 103 (1): 1-14.

WHITING M.F., WHEELER W.C., 1994 - Insect homeotic transformation. - Nature 368: 696.

WHITING M.F., CARPENTER J.C., WHEELER Q.D., WHEELER W.C., 1997 - The Strepsiptera problem: phylogeny of the holometabolous insect orders inferred from $18 \mathrm{~S}$ and $28 \mathrm{~S}$ ribosomal DNA sequences and morphology. - Syst. Biol. 46: 1-68.

WIEGMANN B.M., TRAUTWEIN M.D., KIM J.-W., CASSEL B.K., BERTONE M.A., WINTERTON S.L., YEATES D.K., 2009 - Single-copy nuclear genes resolve the phylogeny of the holometabolous insects. - BMC Biology 7: 34.

WILLMANN R., 2005 - Phylogenese und System der Insecta. In: DATHE H.H., (ed.), Lehrbuch der Speziellen Zoologie, Band I, 5. Teil: Insecta, 2nd edn. Spektrum Akademischer Verlag, Heidelberg, Berlin: 1-65. 